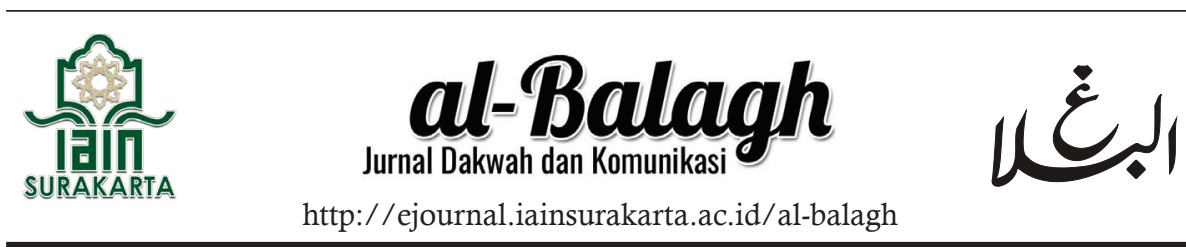

\title{
ANALYSIS OF DA'I COMMUNICATION SKILLS TOWARDS THE MUSLIM CONVERTED KAROMBA COMMUNITY
}

\author{
Arianto* \\ Universitas Hasanuddin
}

\section{Keywords:}

da'i; da'wa communication skills; Muslim converted

\begin{abstract}
Da'wa communication skills are needed in preaching to the converts community because the conditions of converts are different from those of Muslims in general. The success of this da'wa can be achieved if converts as the target of preaching carry out the da'wa message conveyed by the preacher. The research objective was to map the preachers' da'wa communication skills to the converts in Karomba, Pinrang district. This study used a qualitative approach and case study methods, so the primary data were in-depth interviews and observations. In addition, this study uses inductive data analysis. The study results indicate that the preachers apply three da'wa communication skills to the converted Muslim community to support da'wa's success. First, the skills to produce messages, especially messages of faith and morals. Second, the skills to receive and convey messages, mainly using local languages. Third, the skills to interact with the converts community through sharia consultation activities. This research is necessary because the findings of this study can serve as a guide for preachers to increase preaching success, especially preaching to converts.
\end{abstract}

Correspondence:
e-mail: *arianto@unhas.ac.id 


\section{Kata kunci: \\ da'i; keterampilan komunikasi} dakwah; mualaf

\section{Abstrak}

Keterampilan komunikasi dakwah dai dibutuhkan dalam berdakwah terhadap komunitas mualaf karena kondisi mualaf berbeda dengan kondisi kaum muslim pada umumnya. Keberhasilan dakwah tersebut bisa dicapai apabila mualaf sebagai target dakwah melaksanakan pesan dakwah yang disampaikan oleh dai. Tujuan penelitian adalah memetakan keterampilan komunikasi dakwah yang dilakukan oleh para dai terhadap komunitas mualaf Karomba kabupaten Pinrang. Penelitian ini menggunakan pendekatan kualitatif dan metode studi kasus, sehingga data utama adalah wawancara mendalam dan observasi. Selain itu, penelitian ini menggunakan analisis data secara induktif. Hasil penelitian menunjukkan bahwa terdapat tiga keterampilan komunikasi dakwah yang diterapkan oleh para dai terhadap komunitas mualaf sehingga menunjang keberhasilan dakwah. Pertama, keterampilan memproduksi pesan, terutama pesan akidah dan akhlak. Kedua, keterampilan menerima dan menyampaikan pesan, terutama menggunakan bahasa lokal. Ketiga, keterampilan berinteraksi dengan komunitas mualaf melalui kegiatan konsultasi syariah. Penelitian ini menjadi penting karena temuan penelitian ini bisa menjadi pedoman bagi para dai untuk meningkatkan keberhasilan dakwah, terutama dakwah terhadap para mualaf.

How to cite this (APA 7th Edition):

Arianto. (2021). Analysis Of Da'i Communication Skills Towards The Muslim Converted Karomba Community. Al-Balagh: Jurnal Dakwah Dan Komunikasi, 6(1), 35-66. https://doi.org/10.22515/al-balagh.v6i1.3019

\section{INTRODUCTION}

Da'wa communication is planned, aimed at conveying messages that are sourced from or under the teachings of the Al-Qur'an and Al-Sunnah, with the aim that other people can do righteous deeds according to the messages conveyed and to seek happiness in life-based on the pleasure of Allah SWT. Da'wa communication carried out by preachers is to increase 
understanding of religion to change their outlook on life, mental attitudes, and behavior to comply with sharia. Da'i as a communicator in group communication ( $\left.d a^{\prime} w a\right)$, must have communication skills, not only looking at da'wa in a frame, telling the good, and preventing evil. But, da'i must be able to have skills in communication.

Communication skills are one of the most important instruments to achieve the goal. We describe communication skills as the ability and willingness of a person to responsibly take part in message exchange to maximize the effect of the meaning of the message to be understood together. Däi communication skills are observed through da'wa communication behavior. The da'wa communication skills of the da' $i$ in conveying religious messages in various communication settings so that communion (mad'ud) as the target of preaching can be called to follow the teaching of Islam. Such as, da'i who gives da'wa messages to the Muslim converted in Karomba community from Pinrang Regency. He has communication skills for Muslims who are new to the teachings of Islam, still weak belief, to set heart, firm in Islam. Many have problems, ranging from weak faith to a lack of understanding of their new religious teachings and beliefs (Bachtiar, 2013). The Muslim converted in Karomba community needs education of spiritual values in the Islamic religion itself.

In the mountainous region of Karomba, many people convert to Islam. They have known Islam for years, even since 1996, but we believe Islam is limited to two creed sentences. The role of da'i preaches to convey the message of Islamic religious teachings, providing optimal knowledge, through internalizing the values of Islamic education in their lives in the mountainous area of Karomba that is far from access to information and isolated from the wider community (Tahir, Cangara, \& Arianto, 2020).

In the Karomba mountainous area of Pinrang Regency, religious values, education, and worship facilities are very limited. For Friday prayers, the congregation must walk for 2 kilometers to get to the mosque. 
Some villages of the community still adhere to several other religions and beliefs other than Islam. The Department of Religious Affairs of Pinrang Regency once provided religious guidance to this converted community. The Office of Religious Affairs (KUA) provides religious extension twice a month, reduced once a month, and currently, religious extensionists from (KUA) no longer foster the converts. In addition, in a viral story on social media Facebook, a converted child initialed Arjun grade 5 (five) Elementary School wrote a letter about his desire to learn to pray, read the Al-Qur'an, and other Islamic religious values (Tahir et al., 2020).

Similarly, parents cannot foster their children because their knowledge of Islam is still lacking and bestiality in performing worship. So, in carrying out Islamic law, there are still many that have not been carried out. The handling and construction of converts in the Karomba mountainous region have not been optimal, so it is a less supportive factor for converts. Community development through the Ministry of Religious Affairs and other Social Institutions send da'ior ustad to live together for approximately 8 - 24 months in fostering communities in the mountainous village of Karomba.

Communication of da'wa between people who do religious guidance to converts about Islamic knowledge is needed. The presence of a da'i as a communicator has the complement and communication skills of da'wa is necessary, to convey the message of da'wa or information on the values of Islamic diversity, it is easy for the converts to know, understand and apply in daily life of Muslim converted in the Karomba district.

A da'i who presents as a communicator of da'wa who competently listens to their hearts, understands, not to judge them as someone who lacks the beliefs and teachings of Islam. Communicators skillfully motivate others with timely information, are understood together, and two-way (Mina, Jung, \& Ryu, 2021; Weger Jr, Bell, Minei, \& Robinson, 2014; Wolvin, 2012). One form of communication skill preaching that 
attitude and behavior becomes a source of assessment and reference of Muslims converted Karomba community in preaching.

The Muslim converted Karomba community can face. They need a message of preaching in providing the moral values of Islamic teachings in everyday life. One knows which is suitable to do but cannot do so, resulting in everything done awry, but still does not want to do the right thing.

This phenomenon occurs in people who experience religious conversion. Religious messages in the form of symbols or symbols must be deciphered and interpreted so that the role of communication skills preaching da'i in Karomba area can be well received. A da'i can restore the spirit of inmates in living life and can do better things to improve adherence to state rules and obedience to religious orders (Hariyanto, 2017).

The results of previous research found that interpersonal skills are essential skills that an individual or a da'i must possess for interactions to run smoothly, including in implementing da'wa. Interpersonal skills help da' $i$ understand and appreciate others, ultimately leading to success in implementing persuasive preaching (Ismail, Makhsin, Rahim, \& Ghani, 2020; Rosi, 2018; Yusro, 2017).

The results of other studies explain that the skills or competencies that a person needs to have, with the central index values on starting relationships, self-disclosure, affirming displeasure with the actions of others, providing emotional support, and managing interpersonal conflicts (Buhrmester, Furman, Wittenberg, \& Reis, 1988). Another study, entitled "Verbal and Nonverbal Factors Influencing the Success of Da'wa Communication by Ustadz Abdul Somad" found that there are two primary factors behind the effectiveness of da'wa communication. First, verbal factors include comprehensive references and language choices. Second, the nonverbal, which in this case is the use of various platforms 
for disseminating da'wa. The two factors behind Ustaz Abdul Somad's success (Qarni, Syahnan, Harahap, Nasution, \& Fithriani, 2019).

Another study that also discussed da'wa communication to converts was conducted by Tahir et al. (2020). This research resulted in three things. First, the da'i use the face-to-face method in delivering their da'wa. Second, the da'i conveys some religious material in da'wa, for example, fundamental religious values, the virtues of Islam and the beauties of Islam, prayer, and the Koran. Third, there is a change in the attitude of converts after receiving guidance, namely increasing knowledge of the Muslim community about Islam, such as knowledge about the values of monotheism, morality, and sharia.

Casmini (2020) has researched the da'wa strategy carried out by Aisyiyah organization about converts. The research resulted that da'wa to converts was focused on several themes. These themes strengthen the aqidah and Islam, psychological and spirituality, strengthening family resilience, and economic empowerment and welfare. Another research related to da'wa communication strategies was carried out by Nuraedah \& Mutawakkil (2020). The study emphasized that the Tablighi Jamaat used several stages of da'wa strategies. These strategies are: planning to ensure readiness (tafakud); khuruj by paying attention to the practice of intiqali (preaching from different places) and the practice of maqami (preaching to people who live near the mosque), as well as being an agent of change.

The initial difference from this study with other research is to understand the communication skills of preachers in fostering the community of converts. Adaptive and practical communication skills of preachers in situations of faith problems increase understanding and genuine faith in accordance with the teachings of Islamic values for converts. If preaching cannot be understood and accepted by converts, it will cause various problems that often demand change, be it the source of the message or the channel. The lack of da'wa communication skills in 40 
the process of da'wa communication, causing the failure of the expected communication effects because da'wa skills in communication cannot affect converts.

Instead, communication skills help da'i to grasp and understand the Muslim converted Karomba community, he must be rich in thoughts and have great creativity power. Da'i, as the communicator, must have three things in order to be successful: 1) high credibility or confidence; 2) appeal, such as language or geographic resemblance, preferred, popular, processing, or packaging discussion material; 3) strength, has tremendous and vast influence (Muqsi, 2018). Furthermore, they must balance formal preaching based on the sharia topic in the study and preaching based on the description of nature, content, and moral message in sharia and fiqh (Bachtiar, 2013).

Da'wa attempts to improve society by influencing cognitive, affective, and behavioral components and persuading people to act in accordance with Islamic principles (Mubasyaroh, 2017). Therefore, individuals must acquire interpersonal communication skills for interactions to operate well, particularly while conducting da'wa (Ismail et al., 2020; Rosi, 2018; Yusro, 2017).

Communication skills do not appear instantly, but they develop and are applied in persuading, entertaining, or understanding others. Communication skills develop gradually through communication training, seminars, counseling and professional training, and training in acquiring these social skills (Jones Jr, 2017). Communication skills are a person's skill in conveying a coherent message easy for the recipient to understand. Not only is he capable of conveying a message, but he is also a good listener. Communication skills are fundamental to effective communication, so there is no misunderstanding (Rajanuddin, 2014).

Da'i must possess communication skills. The skill to provide the right information and be a good listener. So, with the communication skills, 
da' $i$ can be present to the maximum in front of mad'u. Kelly, Fincham, \& Beach (2003) explained, "communication skills refer to the ability to realize communicative goals while behaving socially appropriately." This skill aims to realize effective communication, behaving socially (Kelly et al., 2003). Another explanation, according to Spence (2003), communication skills are those components of social behavior that are necessary to ensure that individuals achieve their desired outcome from social interaction, essential to ensure the individual performs the desired outcome of social interaction (Hargie, 2006).

Learned communication skills, comprising verbal and non-verbal behavior, require proper initiation and response, maximize feedback from others, require precise timing and control of certain behaviors influenced by applicable contextual factors. Specifically, these skills should be equipped with a level of emotional intelligence (EI). It involves a process in which individuals implement social behaviors directed at purpose, interconnected, situation-appropriate learned and controlled (Hargie, 2006).

Preaching success when $d a^{\prime} i$ successfully directs and invites mad'u to carry out the teachings of Islam. Hence the existence of da' $i$ communication skills is very decisive in the process of da'wa activities (Ismail et al., 2020; Rosi, 2018; Yusro, 2017). This skill needs to be continuously improved, according to Kazdin (Hargie, 2006), identifying the six major elements forming one's skills, as central to the concept of communication skills: 1) learned; 2) comprises certain verbal and nonverbal behaviors; 3) requires initiation and response; 4) maximize rewards available from others; 5) requires precise timing and control over certain behaviors, and 6) influenced by applicable contextual factors.

Communication skills are social skills that involve individual processes implementing social behaviors directed by purpose, interconnected, and situational, learned, and controlled. This research aims 
to understand the communication skills of $d a^{\prime} i$ in the Muslim community converted Karomba community because the approach of the expected effects of a da'wa activity can be various types, especially in the mental and religious coaching of this Muslim converted Karomba. The success of da'wa communication is determined mainly by da'i. The purpose of understanding da'i communication skills in Muslim converted Karomba community. Ability to communicate effectively

There must be resources or preachers, namely da'i, who are skilled, knowledgeable, and of high personal and professional quality for achieving this goal. Da'i is a performer of invitations or a communicator of the ideology. A da'i will serve as the guide, carrying out the treatise's purpose and being summoned to the target of da'wa with proof that demonstrates the truth. A da'i is expected to skillfully tap into and touch the hearts of the individuals he encounters in order to ensure that the mission delivered is acceptable to the people. Preaching is not only aborting obligations, but it is also necessary to have careful planning and thorough evaluation so that the da'wa activities carried out can produce maximum results (Risdiana, 2014). Research on da'wa bil bikmab is one of the da'wa methods da'i to apply to da'wa objects (mad'u), specifically Commercial Sex Workers Pekerja Seks Komersial/PSK). Da'i must understand their situation and condition so that the da'wa can achieve maximum results, namely eradicating and realizing them (PSK) to switch to their normal life (Sunarto AS, 2011).

Da'i must create a role model character with effective models and styles and variations and always consider what mad'u wants. The talks (lecture) can be more effective and readily accepted by various mad'u circles (Murtadlo, 2019). Multiple generality problems occur regardless of the da'i who carries out the noble task is da'wa ilallah (Bachtiar, 2013). Among other terms, communication skills must be possessed by da' $i$ if you want to succeed in persuasive da'wa towards mad'u (Ismail et al., 2020; Rosi, 2018; Yusro, 2017). The results of Gus Dur's colorful da'wa skills can 
suddenly divert a wide range of dramatic, anecdotal facts and then back to severe conclusions (Khasanah, 2019).

The da'wa communication skills of the da' $i$ to converts are essential to study because the da' $i$ of converts to converts is different from the condition of Muslims in general. Converts are individuals or groups of individuals who decide to convert from a non-Islamic religion to Islam. Converts have vulnerabilities to psychological problems (Saifuddin, 2019), so preachers must have the skills to convey messages and da'wa materials so that the vulnerability of converts can be minimized. On the other hand, research related to communication skills of $d a^{\prime} i$ towards converts is also not much. Therefore, this study seeks to explore and map the da'wa communication skills possessed by da'i to preach to converts.

\section{METHODS}

This study used a qualitative approach and case study method. The case study is specific phenomena present in a limited context, although the boundaries between phenomena and contexts are unclear. The case study approach helps researchers gain a complete and integrated understanding of the various facts and dimensions of the case (Yin, 2009). The research site in the mountainous region of Karomba, Pinrang Regency.

The data collected in this study consisted of two types: primary and secondary. The primary data was obtained by in-depth interviews and observations of da'wa communication activities between da'i and Muslim converts community, using recording instruments, cameras, and other writing instruments. The secondary data was obtained by referring to scientific journals, reference books, and available data related to the purpose of this research. Primary data is the leading data obtained directly from field research. Secondary data is supporting data from the primary data. 
The informants in this study are the da'i who provide information for the achievement of this research aim. The choice of da'i as informants because they are da'i sent by the Ministry of Religious Affairs and Social Institutions, actively fostering Muslim converted and staying together to encourage Muslim converted Karomba community. The purposive technique was chosen to determine the number of informants, considering that da'i deliberately communicated dawah in the community of Muslim who converted in Karomba and stayed for approximately 5-9 months in the area, amounting to 6 (six) da'i people as the subject of this study.

The data collection techniques used consist of in-depth interviews, participant observations, document analysis, in-depth interviews, and face-to-face informants for complete and in-depth data. Word is done by observing and recording all the systemic symptoms studied. The primary tool to make direct observations, in addition to the senses, usually the author uses other devices according to the condition of the field, such as notebooks, cameras/mobile phone recordings, and so on. Furthermore, documentation can be written, conception, demographic data, and related theories

Deductions are based on data that has been obtained and has been reinterpreted based on a pre-arranged narrative structure to achieve research objectives. We analyze the collected data inductively, through the process of 1) data reduction, which is selecting or summarizing the data, then seducing and focusing the data on the important things under the research objectives; 2) presentation of data, activities carried out by grouping the data information according to the type; 3) draw its conclusions and verify the data. Then, verify the results of the data analyzed to the informant based on the resulting conclusions.

This study uses member checking and triangulation as data validity techniques. Member checking is a data validity technique that involves research informants to check and confirm research results. Member 
checking aims to minimize conclusion bias in researchers (Birt, Scott, Cavers, Campbell, \& Walter, 2016; Doyle, 2007). The triangulation used is method triangulation. Researchers use various methods, such as interviews and observations, to obtain multiple research data (Heale \& Forbes, 2013; Mertens \& Hesse-Biber, 2012).

\section{RESULTS AND DISCUSSION}

The study results analyzed da'i communication skills like verbal and nonverbal behavior in communicating da'wa with Muslim converted in the Karomba mountains. This behavior occurs when da'i preach or when communicating da'wa to the community of muallaf Karomba. Da'i communication skills refer to the skills to realize the purpose of communicating socially through interaction behavior. The results of da'i communication skills in Muslim converted Karomba community, based on verbal behavior collected by direct observation and in-depth interviews, found that da'i communication skills in Muslim converted Karomba are as follows:

\section{Skills In Da'wa Message Production}

Skills in the production of communication messages da'i in Muslim converted Karomba community related to monitoring the content of da'wa messages during the communication process. This skill includes the integrity of cognitive processes of producing the theme of da'wa messages. Such as communication skills in behaving facilitate a problem solving, communication skills da' $i$ in reframing da'wa messages, issues, choice of precise/simple examples to approach the problem. The disclosure by ustadz MH in his interview said that the message of the theme of da'wa is mainly on aspects of their aqidah, as stated:

"The choice of delivery of the message theme more teaches especially the aqidah-tawhid that discusses the oneness of 
Allah SWT, to be worshipped, for example, through the activity of five-time prayer, to always leave things that smell shirk, believe no more things from the creation of Allah SWT that are contradictory all along. Not worshipping God through prayer may still be a habit before. Giving direct examples through the habits and patterns of behavior of the very noble Prophets,". (Interview results, 28 June 2020)

The choice of message production chooses the message of aqidahtaubid given to convert, considering converts are new Muslims who do not yet have a strong belief in godliness. This communication skill is necessary for $d a^{\prime} i$ as they play an important role in achieving successful preaching activities for Muslim converted Karomba. This skill is also needed in verbal communication behavior, and it helps deliver messages when communicating verbally. Muslim converted messages of information are needed, it helps to produce the intimate relational intercession messages, and messages are referring to efforts to express grievances and problem solving for Muslim converted Karomba in filling their beliefs to Islam. This determines the success and effectiveness of the communication (Syarifah, 2016).

In addition, converts are also given a message about the behavior of Muslims in their daily life in Islam, in the form of moral messages, related to this Ustaz MA said in his interview:

"I convey about the good morals, I think it is good for converts, including how to perform prayer and read the Al-Qur'an. Give an example of how it is as beautiful as something. Let's say we're going to do something beautiful. We recite the hadiths of the Prophet (peace and blessings of Allah be upon him). Like, reading the Al-Qur'an and saying greetings "Assalamualaikum" when meeting people, that's the way it is." (Interview results, 25 June 2020) 
The continuous production of da'wa messages is delivered and sustained in Muslim converted Karomba community. Such as covering morals, beliefs, the practice of five-time prayer, and the guidance of reading the Al-Qur'an. Skills in stringing together a series of framing messages of the essential verbal preaching. As Ustaz MH explains, here are:

"We choose the message of da'wa, for Muslim converted about the teachings of belief, good morality after converting to Islam and reading the Al-Qur'an because sometimes there are also Muslims do not know to read the Al-Qur'an. our preaching material is like that" (Interview results, 11 June 2020)

Communication skills of producing carefully based messages in conveying religious materials, especially for Muslim converted Karomba, explicitly prepared to preach to them, to foster a change in attitude and knowledge of converts, related to this Ustaz MA said that:

"So, the choice of that specific theme, different of course, that was born already Islamic. The first basic understanding of Islam, it should not be us, introduces Islam to the "fanaticism". Secondly, we have to be very patient because really what we teach parents but we like to teach children like, the mention of " $a$ ' ba' ta' tsa ja" we imagine very difficult for the beginning but now, Alhamdulillah." (Interview results, 25 June 2020)

Preaching among Muslim converted Karomba community has its characteristics, because as a community new to Islam, it also has a diverse background, level of education, limited economic ability. Da'wa method requires emphasis, variation, and understanding techniques according to the psychological condition of converts. Da'iplays a vital role in the success of providing an understanding through application in daily life. Inner self skills through the disclosure of ideas, opinions, interests, experiences, and feelings. 
The skill of choice is appropriate and applied in terms of situational Muslim converted in the belief of Islam religion because of an evaluative assessment of cognitive and behavioral qualities. The primary criteria used to guide the correct and path form the information necessary for Muslim converted to communicate continuously and competently.

Based on this explanation, producing messages is an essential aspect in communicating (Greene, 1997), especially in preaching to the converts. Messages conveyed to converts should be based on the needs of converts, both conditions related to religion and daily matters.

In addition, producing messages is also accompanied by high sensitivity regarding the message so that communicators (in this case are $d a$ i) can create comfortable communication, especially for converts (Burleson, 1985). On the other hand, message production skills are also related to understanding the recipient's age (Nussbaum \& Baringer, 2000) so that the resulting message will be in accordance with the age characteristics of the recipient of the message. Production of the right message then contributes to communication success (Mahajan, 2015), both the success of communication and the success of the recipient of the message in changing his behavior.

\section{Skill In Receive And Convey Da'wa Messages}

Skill acceptance of order da'i is a skill in delivering da'wa orders on the aspects of understanding, interpretation, and storage of order for Muslim converted Karomba. Skill relates to da'i's knowledge through da'wa's theme, which is later learned in well applied, coached, and positively affected through direct or indirect behavioral activities. The da'wa's order towards God is the most honorable and primary position for a servant, so it will not happen except with knowledge.

The skill of communication da'i in receiving orders on Muslim converted Karomba communities strives to call for or invite, the resilient in 
delivering its moral orders to Muslim converted, using excellent language or identified by the spoken language, Bugis dialect. Their dominant Bugis language is straightforward. They approach as members of the Bugis ethnicity.

Using speech-language for a $d a^{\prime} i$ in conveying the pappaseng of oral $d a^{\prime} w a$ is an integral part and owned by the da'i under the values of religious understanding, especially in communities that just believe Islam their religion. One example is expressing the word prevention through the Bugis word "pemmali-pemmall" which is socialized early in the life of the Muslim converted Karomba community.

Appropriate language is the key to success in receiving and conveying (Belov et al., 2018), especially da'wa messages (Ahsan, 2019; Yuliani, 2019). Language, especially local languages, plays an important role in closing the distance between preachers and converts. When the da'i conveys da'wa in the local language or a language that the converts understand, it will cause the converts to accept and understand the purpose of the da'wa material (Ahsan, 2019). In addition, if the da'i use the local language, it will generate interest in the recipients of the da'wa, in this case, the converts (Yuliani, 2019).

It applies this skill da'i by grouping converts to be given da'wa messages and making it easier for them to receive such messages, discussions, and direct applications, given that converts are not like Muslims from birth who already have Islamic basics previously. Receiving messages through the division of target groups and routinely carrying cauterization out groups of children and adults. Related to this Ustaz MS says that:

"To facilitate the acceptance of messages, I divide or create a coaching program for children, mothers and fathers through discussion activities, and direct practice, in daily activities we often do.” (Interview results, 28 June 2020) 
Rahmatullah (2016) stated that a good da'wa is da'wa that is carried out by adjusting based on the characteristics of the target of $d a^{\prime} w a$ or mad'u. For example, delivering da'wa to scholars and scientists differs from delivering da'wa to the public in general. Faizah \& Effendi (2018) argue that mad' $u$ characteristics that need to be considered in preaching are personality, intelligence, knowledge, skills, values, and roles. In addition, a good da'wa must pay attention to psychological aspects, including age (Muhadi, 2019). Thus, da'wa has different forms and methods for each development phase, starting from children, adolescents, adults, and the elderly. Thus, grouping in preaching can be applied by the da' $i$ to converts of various ages.

Other explanations, such as excerpts of the statement da'i initials MA, to strengthen the message of da'wa usually also use Bugis language and terms that they can easily understand, and to strengthen the content of da'wa message, such as in the interview results:

"For example, teaching tauhid, often we emphasize the aspect of "pammali", for example, "pammall" if not wudhu or tayammum before prayer. To make it easier for them to remember messages. We teach taubid, such as using Bugis," $t a$ ' ppikiri ki" and "jangki" forgot the punishment and practice of Allah SWT. It means there is the God that exists, and they don't think about what it is, where it is. We have to give a fundamental understanding. This makes the message easier to be understood." (Interview results, 25 June 2020)

The content of the message of da'wa that they do, namely trying to build and increase Muslim converted to have an attitude, for example, the attitude of "ta'awun" (helping each other) in the context "amar ma'ruf nahi munkar". It was emphasized to practice as a form of the promise. An effort is being made to instill an understanding and growing awareness of Islamic values. Islam is a religion that Allah sent down through His 
messenger, Muhammad, and it contains values that help build a whole human being, that is, to balance the spiritual and physical-mental material of humanity in order to achieve welfare and happiness in the world's life. Communication skills for da'i are considered as innovations in the development of Muslim converted Karomba community and creating good social interaction in their group.

In creating a relationship between the converts, there appears to be a change in how the Karomba convert community views his daily behavior and their normality in his social life. Positive habits for women to wearing hijab and five times pray on time. This skill provides emotional support for optimizing interpersonal communication between two personals, calming down, and comforting Muslim converted when depressed and problematic.

This da'i communication skill constructing speech-language is a form of transmission, witness, and transformation of values that conform to Islamic values. Although da'wa's messages in the language of speech are the frame of culture in society, they are still related to the principles: qaulän sadìdān, qaulān balìghàn, qaulān ma'rǘän, qaulān karimān, qaulān layyinān, and qaulān maysūrān. Da'wa messages are also exemplified by the da'i lives itself.

\section{Skills In Interacting}

Da'i communication skills in interacting with Muslim converted Karomba is related to the smoothness and transfer of information. Da'i skills in the form of practical and physiological responses that impact relationship satisfaction and stability. According to Akil (2015), da'i should have interaction skills in delivering their da'wa, so that the da'wa process can be interactive Interactive communication is defined as a mode of communication in which the messenger's stimulus is interpreted and responded to by the message's recipient. Two-way communication occurs (Karlsson, 2013; Nordby, 2011; Shan et al., 2015). Achieving interactive 
communication in the context of da'wa is critical because it shows that $d a^{\prime} i$ is successful in drawing the attention of their target audience and motivating them to receive the da'wa.

Da'i communication occurs in groups to communicate information with the Muslim converted Karomba people. Because converts are new Muslims, unlike Muslims born into the faith, it is simpler for them to assemble and talk in groups of children and adults. We spoke about their everyday routines. Ustaz MA explained that:

"I've had nine months here. We regularly gather at a certain time. To interact, learn, directly group fathers, mothers, and children every day, especially every prayer, studying first and then continued with educational materials. If those mothers in a week range from one to three nights a week. For fathers around one-two hours, usually, the old one is a discussion, in the form of a question and answer." (Interview results, 25 June 25 2020)

In the Karomba highlands, the Muslim converted Karomba community interacts on a daily basis under the direct direction of the appointed $d a$ ' . He is creating activity for mothers, fathers, and children daily in mushalla, learning, acquiring knowledge, and conversing about Islam. Direct interaction skills $d a$ ", using the phrase "shariah consultation" and religious lectures, persuasion, being readily recognized, comprehending muslim converts, and developing and establishing views or beliefs as transmitted. As said by Ustaz MA in his interview:

"I slowly saw them practice what they had received from us, whether in the mushallah, when we met, or wherever we met. Anyway, his da'wa communication is everywhere, of course with jokes, a funny example in trying to do good things. Especially exemplifying the behavior of the Prophet Muhammad." (Interview results, 25 June 2020) 
Da'i skill uses materials or messages of Islamic teaching values, friendship, jokes, and a relaxed and intimate atmosphere so that da'wa's message is more communicative. It is not uncommon for da'wa to incorporate jokes and humor. Certain da'i employ jokes and humor to create connections with the recipients of da'wa and soften da'wa's mood. Jokes and humor in da'wa will foster intimacy between the da'i and the recipients of da'wa (in this case, converts), allowing the recipients of da'wa to receive and carry out the message of da'wa free of coercion and pressure. Additionally, jokes and comedy demonstrate the da'is equality with the receivers of da'wa (Abdullah, Muhid, \& Wahyudi, 2020). The use of jokes and humor in da'wa also tries to attract the interest of the recipients of da'wa (Nurcholis, Hidayatullah, \& Laila, 2019), so that those who receive da'wa teachings are not easily bored. Along with humor, da'wa with an element of friendship establishes an equal relationship between the $d a^{\prime} i$ and the da'wa receiver and fosters unity (Nuraedah \& Mutawakkil, 2020).

This falls under the category of the communication process's purpose, which includes da'wa communication. For each Muslims converted Karomba, the objective of this communication varies. However, it is divided into three subcategories: Goals for self-presentation (who and how they want to be recognized), and relational goals (how to develop, maintain and end relationships), and instrumental purposes such as obtaining compliance (getting someone to do something), obtaining necessary knowledge, or soliciting assistance (Abdullah, Ling, Sulaiman, Radzi, \& Putri, 2020; Avia, Sánchez-Bernardos, Sanz, Carrillo, \& Rojo, 1998; Lewis \& Neighbors, 2005). It uses different communication techniques on various parties depending on the intended purpose of communication. They may require informal communication, while other circumstances may require formal communication. This is as explained in the theory of communication accommodation. The theory of communication 
accommodation explains that; when people communicate, they adjust their vocal and speech patterns to accommodate the needs of message recipients (Rodriguez, 2017). Communication skills process the use of language "message code." Each individual is not equally skilled in using a particular language in all communication processes.

In addition, da'wa material adjusts to the background of converts, especially tawhid, prayer problems, morals, reading the Al-Qur'an, fasting, and others. This skill can provide basic and practical knowledge, in the direct sense can be practiced such as prayer and prayers strengthen the truth of Islam.

Communication skills must serve as a flow of information, perception, and understanding among various stakeholders, methods, media, and means of communication. Aspects of communication and making it comprehensive suggest that there are so many things going on in the process (Hardjati \& Febrianita, 2019).

A skilled person has excellent communication skills, if able to communicate with others, a way that fulfills one's rights, requirements, satisfaction, or obligations without neglecting the rights, dignity, or duties of others in the exchange of messages. The communication process is a pattern of learning tutorials and dialogues. The activity constructed a communication model tailored to social, psychological, and situational strata (Hartono, 2016). Social encounters, reciprocity between da'i and Muslim converted to focus on the results in knowledge, attitudes, and behaviors. 
Table 1.

Communication Skills In Muslim Converted Karomba Community

\begin{tabular}{|c|c|c|c|}
\hline No. & $\begin{array}{c}\text { Communication Skills } \\
\text { Da'i }\end{array}$ & Communication Process Of Da'wa & Method \\
\hline 1. & $\begin{array}{l}\text { Skills in Da'wa Message } \\
\text { Production }\end{array}$ & $\begin{array}{l}\text { Participatory and interactive, The } \\
\text { message of da'wa builds relationships } \\
\text { in the community Muslim converted, } \\
\text { and positive feedback. }\end{array}$ & $\begin{array}{l}\text { A s sis t a n c e, } \\
\text { dialogue, Islamic } \\
\text { studies. }\end{array}$ \\
\hline
\end{tabular}

2. Skill in Receive And Play a good role and be accepted Monitoring and Convey Da'wa Messages every Muslim converted Karomba Literacy

3. Skills in Interacting Community motivation is activated Assistance, based on relationships and dialogue, relevance of shared goals Islamic studies

$D a^{\prime} i$ communication skills in the Muslim converted Karomba community in the process of da'wa communication have several aspects, including participatory and interactive. Da'wa's message builds relationships in Muslim converted Karomba, and positive feedback, plays a good role and be accepted by every Muslim converted, and they activate community motivation. Communication skills in da'wa communication for preachers are to change converts (thoughts, feelings, behavior) from a severe condition to a moral condition. Methods used in faith guidance and coaching are mentoring, dialogue, assistance in Islamic studies, literacy.

They acquire spirituality and faith through the stages of conversion, knowledge and motivation synthesis, reintegration of personality that necessitates adaptation to new ideas, acceptance of new religious conceptions, and the emergence of consciousness to carry out new religious teachings (Jayos, Ghani, Tahir, Jasmi, \& Bandar, 2015; Setiyani $\&$ Muktafi, 2020). In addition, the guidance also helps him to adapt to the new environment. Individuals who undergo conversion, as indicated by Saifuddin (2019), require supervision. He was able to deepen his convictions and increase his religiosity as a result of the guidance. Furthermore, the assistance assists him in adjusting to his new surroundings. 
According to the Goffman notion, the da'i's self-image in preaching becomes a reference for controlling impressions, including verbal and nonverbal communication signals. Da’i preaching communication abilities can manifest themselves in the social context on a permanent or momentary basis (Sulaeman, Sulastri, \& Nurdin, 2018). The appearance of one's self as an identity is deliberately done so that they can accept it when preaching. In a communication perspective, they form the identity of the preacher through communication with the congregation. Identity is owned, generated through several interactions and communications with the community. These interactions are very situational, determined by when, where, and at what events and with whom they are dealing.

In presenting himself, då depends on his ability to interpret situations and generate situational skills. They can use his skills as a frame of reference, such as a commendable personality, proficiency, superior knowledge, and ability to master the congregation. The achievement of communication skills is complicated not only by the situational aspects of language use but also by language codes and communication habits in diverse cultures and subcultures in various institutions and regions.

The process of Islamic da'wa communication for converts attempts to call or invite, and Muslim converted to do bad and prevent evil. Da'i communication abilities in the Muslim converted Karomba community can be ideally thriving if backed by an excellent da'wa communication procedure. Da'i should also pay attention and remember the communicators' skills and the message given to the Muslim converted Karomba community to establish an active communication process.

Da'i communication skills are not just used, but through a long and learned process, as the ability to interact in a particular social context. These specific ways are socially acceptable or valued and are personal, mutually beneficial, or beneficial, especially to the Muslim converted Karomba community. Da'i for a convert is the key and foundation in 
practicing Islam. Strengthen faith in God, angels, books, apostles, last days, Allah's Qadha, and Qadar. Strengthening aqidah towards devout Muslims will accustom the converts to deepening the science of religion, carrying out and carrying out correctly as taught in Islam.

The da'wa carried out by the da'i to the converts in Karomba can be considered to fulfill four forms of da'wa activities according to Rosyid (2020): 1) Tabligh and ta'lim are carried out with intelligence/enlightenment through socialization, internalization, and externalization of the values of Islamic teachings, 2) Irsyad is carried out in the context of solving psychological problems through personal, family, or group counseling guidance, 3) Tathwir (community development) by institutionalizing Islamic values in social life (cultural da'wa), and 4) Tadbir (community empowerment management) with the main activities of policy formulation, program planning, organizing, and evaluation.

\section{CONCLUSION AND SUGGESTION}

\section{Conclusion}

A professional da'wa is distinguished not only by its ability to communicate da'wa, but also by its skills in producing the Shahada and moral messages. Also, the skills in receiving messages using Bugis language and terms that impact if they are violated, and skills in group communication interactions that are interactive through the concept of sharia consultation. Communication skills of $d a^{\prime} i$ with converts to the Karomba community are a core value that must be possessed to fulfill the da'wa needs of Muslims in maintaining their beliefs. Without preaching, Muslim community would not exist.

Positive da'wa communication serves to transform Islam values as teaching into reality, particularly for the Muslim converted Karomba community, which is based on Islamic teachings based on the Al-Qur'an and Al-Sunnah. Positive da'wa communication abilities will result in positive attitudes and behavior patterns, making this communication positive. 


\section{Suggestion}

Every preacher must possess communication skills to achieve their da'wa goals. These skills are essential in building self-confidence and building positive relationships with mad'u. It takes serious efforts from all elements of civil and government in Indonesia, especially preachers, to take part together in da'wa communication in developing Islamic teachings. Therefore, the development of da'wa communication skills must be learned and improved through the participation of all parties through training activities, seminars, workshops, and ongoing training, if you want to carry out effective persuasive da'wa in mad'u.

\section{REFERENCES}

Abdullah, A. A., Muhid, A., \& Wahyudi, W. E. (2020). "Humor In Da'wah": Socio-Linguistic Analytic Of Kyai Ishaq Latif Da'wah From Pesantren Tebuireng Jombang. Ilmu Dakwab: Academic Journal For Homiletic Studies, 14(2), 211-230. https://doi.org/10.15575/idajhs. v14i2. 9053

Abdullah, Z., Ling, T. Y., Sulaiman, N. S., Radzi, R. A. M., \& Putri, K. Y. S. (2020). The Effects Of Verbal Communication Behaviors On Communication Competence In The Pharmaceutical Industry. Journal of Critical Reviews, 7(12), 697-703. https://doi. org $/ 10.31838 /$ jcr.07.12.125

Ahsan, A. A. (2019). Existence Of Regional Languages In Submission Of Islamic Dakwah. IDEAS: Journal Of Language Teaching And Learning, Linguistics And Literature, 7(1), 109-113. https://doi. org/10.24256/ideas.v7i1.727

Akil, M. A. (2015). Online Da'wah (Islamic Missionary Work) Model (A Study On The Use Of The Internet As Missionary Media By Muballigh/Muballighah Of UIN Alauddin). Journal Of Islam And Science, 02(01), 73-102. https://doi.org/10.24252/jis.v2i1.2169 
Avia, M. D., Sánchez-Bernardos, M. L., Sanz, J., Carrillo, J., \& Rojo, N. (1998). Self-Presentation Strategies And The Five-Factor Model. Journal Of Research In Personality, 32(1), 108-114. https://doi. org/10.1006/jrpe.1997.2205

Bachtiar, M. A. (2013). Dakwah Kolaboratif: Model Alternatif Komunikasi Islam Kontemporer. Jurnal Komunikasi Islam, 03(01), 152-168. https://doi.org/10.15642/jki.2013.3.1.\%25p

Belov, S., Kropachev, N., Latukha, M., Orlova, E., Baeva, E., \& Bondar, V. (2018). The Role Of Language In The Communication Process Between Business And Government: Evidence From Russian Firms. Journal Of East-West Business, 24(4), 481-491. https://doi. org/10.1080/10669868.2018.1463341

Birt, L., Scott, S., Cavers, D., Campbell, C., \& Walter, F. (2016). Member Checking: A Tool To Enhance Trustworthiness Or Merely A Nod To Validation? Qualitative Health Research, 26(13), 1802-1811. https://doi.org/10.1177/1049732316654870

Buhrmester, D., Furman, W., Wittenberg, M. T., \& Reis, H. T. (1988). Five Domains Of Interpersonal Competence In Peer Relationships. Journal Of Personality And Social Psychology, 55(6), 991-1008. https:// doi.org/10.1037/0022-3514.55.6.991

Burleson, B. R. (1985). The Production Of Comforting Messages: SocialCognitive Foundations. Journal Of Language And Social Psychology, 4(3-4), 253-273. https://doi.org/10.1177/0261927X8543006

Casmini. (2020). Analysis Of Muallaf' Aisyiyah Da'wah Strategy. Ilmu Dakwah: Academic Journal For Homiletic Studies, 14(1), 151-166. https://doi.org/10.15575/idajhs.v14i1.9238

Doyle, S. (2007). Member Checking With Older Women: A Framework For Negotiating Meaning. Health Care For Women International, 28(10), 888-908. https://doi.org/10.1080/07399330701615325

Faizah, \& Effendi, L. M. (2018). Psikologi Dakwah. Jakarta: Kencana.

Greene, J. O. (1997). Message Production: Advances In Communication Theory. Milton Park, Abingdon-on-Thames, Oxfordshire, England, UK: Routledge.

Hardjati, S., \& Febrianita, R. (2019). The Power Of Interpersonal Communication Skill In Enhancing Service Provision. Journal of Social Science Research, 14, 3192-3199. 
Hargie, O. (2006). The Handbook of Communication Skills (3rd Ed). Milton Park, Abingdon-on-Thames, Oxfordshire, England, UK: Routledge.

Hariyanto. (2017). Komunikasi Persuasif Da’i Dalam Pembinaan Keagamaan Narapidana (Studi Pada Lembaga Pemasyarakatan Wanita Kelas II A Bandar Lampung). Jurnal Ilmu Dakwah, 37(2), 181-197. https://doi.org/10.21580/jid.v37.2.2704

Hartono, R. (2016). Pola Komunikasi Di Pesantren: Studi Tentang Model Komunikasi Antara Kiai, Ustadz, Dan Santri Di Pondok Pesantren TMI Al-Amien Prenduan. Al-Balagh: Jurnal Dakwah Dan Komunikasi, 1(1), 67-100. https://doi.org/10.22515/balagh. v111.60

Heale, R., \& Forbes, D. (2013). Understanding Triangulation In Research. Evid Based Nurs, 16, 98. https://doi.org/10.1136/eb-2013-101494

Ismail, N., Makhsin, M., Rahim, S. I. A., \& Ghani, B. A. (2020). Interpersonal Communication Skill And Da'wah Fardiyah Approach In Sustainable Islamic Spiritual Mentoring. In N. Kaur \& M. Ahmad (Eds.), Charting A Sustainable Future Of ASEAN In Business And Social Sciences (pp. 79-86). https://doi.org/10.1007/978-981-153859-9_8

Jayos, S., Ghani, F. A., Tahir, L. M., Jasmi, K. A., \& Bandar, N. F. A. (2015). System Support In Counselling Among Muslim Convert Clients In Malaysia. Journal of Cognitive Sciences And Human Development, 1(1), 74-81. https://doi.org/10.33736/jcshd.189.2015

Jones Jr, R. G. (2017). Communication In The Real World. Boston, Massachusetts, United States: FlatWorld.

Karlsson, M. (2013). Representation As Interactive Communication. Information, Communication \& Society, 16(8), 1201-1222. https:/ / doi. org/10.1080/1369118X.2012.757633

Kelly, A. B., Fincham, F. D., \& Beach, S. R. H. (2003). Communication Skills In Couples: A Review And Discussion Of Emerging Perspectives. In J. O. Greene \& B. R. Burleson (Eds.), Handbook Of Communication And Social Interaction Skills (pp. 723-751). Mahwah, United State: Lawrence Erlbaum Associates Publishers.

Khasanah, F. (2019). Metode Dakwah Gus Dur Dan Era Revolusi Industri 4.0. Al-Balagh: Jurnal Dakwah Dan Komunikasi, 4(2), 317-336. 
Al-Balagh: Jurnal Dakwah dan Komunikasi,

Vol. 6, No. 1, January - June 2021, pp. 35 - 66, DOI: https://doi.org/10.22515/al-balagh.v6i1.3019

ISSN: 2527-5704 (P) ISSN: 2527-5682 (E)

https://doi.org/10.22515/balagh.v4i2.1818

Lewis, M. A., \& Neighbors, C. (2005). Self-Determination And The Use Of Self-Presentation Strategies. Journal Of Social Psychology, 145(4), 469-490. https://doi.org/10.3200/SOCP.145.4.469-490

Mahajan, R. (2015). The Key Role Of Communication Skills In The Life Of Professionals. Journal Of Humanities And Social Science, 20(12), 36-39.

Mertens, D. M., \& Hesse-Biber, S. (2012). Triangulation And Mixed Methods Research: Provocative Positions. Journal Of Mixed Methods Research, 6(2), 75-79. https://doi.org/10.1177/1558689812437100

Mina, K. S., Jung, J. M., \& Ryu, K. (2021). Listen To Their Heart: Why Does Active Listening Enhance Customer Satisfaction After A Service Failure? International Journal Of Hospitality Management, 96. https://doi.org/10.1016/j.ijhm.2021.102956

Mubasyaroh. (2017). Strategi Dakwah Persuasif Dalam Mengubah Perilaku Masyarakat. Ilmu Dakwah: Academic Journal For Homiletic Studies, 11(2), 311-324. https://doi.org/10.15575/idajhs.v12i.2398

Muhadi, U. (2019). Membangun Efektifitas Dakwah Dengan Memahami Psikologi Mad'u. Jurnal Dakwah Dan Komunikasi, 4(2), 169-186. https://doi.org/10.29240/jdk.v4i2.1251

Muqsi. (2018). Hubungan Dakwah Dan Komunikasi. Jurnal Peurawi, 1(1), 1-9. http://dx.doi.org/10.22373/jp.v1i1.2763

Murtadlo, A. (2019). Kharisma Pendakwah Sebagai Komunikator. Jurnal Spektrum Komunikasi, 7(1), 1-16. https://doi.org/10.37826/ spektrum.v7i1.24

Nordby, H. (2011). The Nature And Limits Of Interactive Communication: A Philosophical Analysis. Seminar.Net: International Journal Of Media, Technology And Lifelong Learning, 7(1), 18-33.

Nuraedah, \& Mutawakkil. (2020). The Da'wah Communication Strategy Of Jamaah Tabligh In Sub-District Of Tondo, Palu City. Ilmu Dakwah: Academic Journal For Homiletic Studies, 14(2), 297-316. https://doi. org/10.15575/idajhs.v14i2.10220

Nurcholis, A., Hidayatullah, S. I., \& Laila, I. (2019). Inspirational Da'wah For Millennial Generation: Study At IAIN Tulungagung. Jurnal MD, 5(2), 165-180. https://doi.org/10.14421/jmd.2019.52-03 
Nussbaum, J. F., \& Baringer, D. K. (2000). Message Production Across The Life Span: Communication And Aging. Communication Theory, 10(2), 200-209. https://doi.org/10.1111/j.1468-2885.2000. tb00189.x

Qarni, W., Syahnan, M., Harahap, I., Nasution, S., \& Fithriani, R. (2019). Verbal And Nonverbal Factors Influencing The Success Of Da'wah Communication By Ustadz Abdul Somad. KnE Social Sciences: The Second Annual International Conference on Language and Literature Volume 2019, 804-812. https://doi.org/10.18502/kss. v3i19.4906

Rahmatullah, R. (2016). Analisis Penerapan Metode Dakwah Berdasarkan Karakteristik Mad'u Dalam Aktivitas Dakwah. Jurnal Mimbar: Media Intelektual Muslim Dan Bimbingan Rohani, 2(1), 55-71. https:// doi.org/10.47435/mimbar.v2i1.286

Rajanuddin, A. M. (2014). Keterampilan Komunikasi Pustakawan Informasi Perpustakaan STAIN Samarinda. Lentera, XVI(2), 198 209. https://doi.org/10.21093/lj.v16i2\%20Desember.180

Risdiana, A. (2014). Tranformasi Peran Da’i Dalam Menjawab Peluang Dan Tantangan. Jurnal Dakwah, XV(2), 433-451. https://doi. org/10.14421/jd.2014.15210

Rodriguez, P. A. (2017). Conceptual Model Of Communication Theories Within Project Process. INNOVA Research Journal, 2(3), 42-51. https://doi.org/10.33890/innova.v2.n3.2017.131

Rosi, B. (2018). Penguatan Kapasitas Soft Skill “Calon Da'i” Melalui Tugas Pengabdian Masyarakat. 'Ulûmunâ: Jurnal Studi Keislaman, 4(2), 150-169. https://doi.org/10.36420/ju.v4i2.3500

Rosyid, M. (2020). Optimizing Da'wah From The Perspective Of Da'wah Management: A Case Study Of The Ex- Samin Muallaf In Kudus, Central Java. Jurnal Al-Bayan: Media Kajian Dan Pengembangan Ilmu Dakwah, 26(2), 270 - 303. https://doi.org/10.22373/albayan. v27i1.6846

Saifuddin, A. (2019). Psikologi Agama: Implementasi Psikologi Untuk. Memahami Perilaku Beragama. Jakarta: Kencana.

Setiyani, W., \& Muktafi, M. (2020). The Resilience Of Muslim Converts In Understanding Islam: The Role Of Al-Akbar Mosque For Post-Conversion Accompaniment. Teosofi: Jurnal Tasawuf Dan 
Pemikiran Islam, 10(2), 302-324. https://doi.org/10.15642/ teosofi.2020.10.2.303-325

Shan, L. C., Panagiotopoulos, P., Regan, Á., De Brún, A., Barnett, J., Wall, P., \& McConnon, A. (2015). Interactive Communication With The Public: Qualitative Exploration Of The Use Of Social Media By Food And Health Organizations. Journal Of Nutrition Education And Behavior, 47(1), 104-108. https://doi.org/10.1016/j. jneb.2014.09.004

Spence, S. H. (2003). Social Skills Training With Children And Young People: Theory, Evidence And Practice. Child And Adolescent Mental Health, 8(2), 84-96. https://doi.org/10.1111/1475-3588.00051

Sulaeman, Sulastri, I., \& Nurdin, A. (2018). Dramaturgi Komunikasi Dakwah Para Da’i Di Kota Ambon: Pola Pengelolaan Kesan Di Panggung Depan. Jurnal Komunikasi Islam, 8(1), 86-110. https:// doi.org/10.15642/jki.2018.8.1.86-110

Sunarto AS, H. A. (2011). Dakwah Pada Pekerja Seks Komersial. Jurnal Komunikasi Islam, 01(01), 1-15.

Syarifah, M. (2016). Budaya Dan Kearifan Dakwah. Al-Balagh: Jurnal Dakwah Dan Komunikasi, 1(1), 23-38. https://doi.org/10.22515/ balagh.v1i1.43

Tahir, A., Cangara, H., \& Arianto, A. (2020). Komunikasi Dakwah Da' Dalam Pembinaan Komunitas Mualaf Di Kawasan Pegunungan Karomba Kabupaten Pinrang. Jurnal Ilmu Dakwah, 40(2), 155-167. https://doi.org/10.21580/jid.v40.2.6105

Weger Jr, H., Bell, G. C., Minei, E. M., \& Robinson, M. C. (2014). The Relative Effectiveness Of Active Listening In Initial Interactions. International Journal Of Listening, 28(1), 13-31. https://doi.org/10. 1080/10904018.2013.813234

Wolvin, A. D. (2012). Listening, Understanding, And Misunderstanding. 21st Century Communication: A Reference Handbook, 137-146. https:// doi.org/10.4135/9781412964005.n16

Yin, R. K. (2009). Case Study Research: Design and Methods (4th Ed). London, United Kingdom: Sage Publications.

Yuliani. (2019). The Role Of Language In The Development Of Islamic Da'wah In Indonesia. Jurnal Kelola: Jurnal Ilmu Sosial, 2(2), 129-136. https://doi.org/10.15575/jk.v2i2.8088 
Yusro, N. (2017). Urgensitas Kepribadian Da`i Dalam Berdakwah. Jurnal Dakwah Dan Komunikasi, 2(1), 73-100. https://doi.org/10.29240/ jdk.v2i1.278 
Al-Balagh: Jurnal Dakwah dan Komunikasi,

Vol. 6, No. 1, January - June 2021, pp. 35 - 66, DOI: https://doi.org/10.22515/al-balagh.v6i1.3019 ISSN: 2527-5704 (P) ISSN: 2527-5682 (E) 